\title{
Semi-natural regeneration and conservation in agroforestry system models on small-scale farmers
}

\author{
PRIYONO SURYANTO ${ }^{1, \bullet}$, RONGGO SADONO ${ }^{2}$, AISYA YOHANIFA ${ }^{1}$, MUHAMMAD HABIB WIDYAWAN ${ }^{3}$, \\ TAUFAN ALAM ${ }^{3, v}$ \\ ${ }^{1}$ Department of Silviculture, Faculty of Forestry, Universitas Gadjah Mada. Jl. Agro No. 1, Bulaksumur, Sleman 55281, Yogyakarta, Indonesia \\ Tel.: +62-274-512102, Fax.: +62-274-550541, ^email: psuryanto@ugm.ac.id. \\ ${ }^{2}$ Department of Forest Management, Faculty of Forestry, Universitas Gadjah Mada. Jl. Agro No. 1, Bulaksumur, Sleman 55281, Yogyakarta, Indonesia \\ ${ }^{3}$ Department of Agronomy, Faculty of Agriculture, Universitas Gadjah Mada. Jl. Flora No. 1, Bulaksumur, Sleman 55281, Yogyakarta, Indonesia
}

Manuscript received: 10 December 2020. Revision accepted: 17 January 2021.

\begin{abstract}
Suryanto P, Sadono R, Yohanifa A, Widyawan MH, Alam T. 2021. Semi-natural regeneration and conservation in agroforestry system models on small-scale farmers. Biodiversitas 22: 858-865. The regeneration capacity can provide an overview of the abundance of species so that it can be used to determine the potential and opportunities for the sustainability of agroforestry systems. The purpose of this study was to determine the capacity of semi-natural regeneration in agroforestry system models for small-scale farmers. The study was carried out in Banaran Sub-district, Playen District, Gunungkidul Regency, Special Province of Yogyakarta, Indonesia. The observation was conducted on plant diversity, floristic composition, and agroforestry contribution. The results showed that the mixed cropping (MC) model had a higher total of individuals and diversity compared to the trees along with border (TAB) model in the sapling and seedling level. The MC model was relatively shorter to the waiting time of harvesting compared to the TAB model. The MC models weakness was the relatively high competition and the lack of opportunities to growing annual crops. The TAB model had an advantage in developing annual crops in an agroforestry system, while longer in waiting time for harvesting perennial crops. This study recommends annual pruning in the MC model for optimal stand growth, while in the TAB model, it is the enrichment planting in sapling and seedling levels.
\end{abstract}

Keywords: Agroforestry, conservation, mixed cropping, regeneration, trees along border

Abbreviations: $D$ : Simpson's dominance index, ${ }^{0} D$ : species richness, ${ }^{I} D$ : typical species, ${ }^{2} D$ : dominant species, ${ }^{2} D /{ }^{\rho} D$ : evenness factor, $H^{\prime}$ : Shannon's entropy index, MC: mixed cropping, TAB: trees along border, $\varnothing$ : diameter, $\alpha$ : alpha diversity, $\beta$ : beta diversity, $\Upsilon$ : gamma diversity, $\beta_{s \phi r}$ : Sørensen's pairwise dissimilarity index, $\beta_{\text {sim }}$ : spatial turnover, $\beta_{\text {nes }}$ : nestedness

\section{INTRODUCTION}

The biggest challenge related to climate change, food security, and decreasing agricultural resources is developing an excellent agricultural system that can increase farmers' income (Xu et al. 2019). Agroforestry provides a solution to various problems, i.e., enable farmers to use available land resources at lower environmental costs effectively, and produce various products (i.e. timber, food, fuelwood, fodder, etc) at different times (World Agroforestry Centre 2011).

Agroforestry is the collective name for land-use systems and technology in which the woody perennials are integrated with annual crops and animals in the same land management unit (FAO 2015). Agroforestry forms a strategic synergy between agricultural, forestry, and environmental sectors, which is necessary for the reform of more appropriate natural resource management with the principles of sustainability and accelerated prosperity (Sabarnurudin et al. 2011). In Indonesia, the agroforestry system is widely applied in community forests. Community forest management is a model of social forestry or community forestry. In this model, local communities are directly responsible for forest management, including protection activities, and receive benefits for their efforts (De Royer et al. 2018).

The area of community forests in Gunungkidul Regency is about $44,110.87$ hectares. It is $56 \%$ of the total community forests in the Special Province of Yogyakarta, Indonesia (Yogyakarta Provincial Environment and Forestry Service 2019). The community forests have a great potential in production, thus contributing to the national forestry sector (Muschler 2016). The agroforestry system implemented in community forests depends on the level of tree population density and the nature of the local community. Different cropping patterns will have an impact on land management and productivity (Bowler et al. 2011).

The agroforestry models mostly found in Gunungkidul are mixed cropping (MC) and trees along border (TAB). These models are selected because relatively easy to implement and provide higher products of agricultural and forestry than other models (Suryanto et al. 2005). TAB is the tree cropping pattern on the edge of the forest, while agricultural products in the middle. Trees planted along the edge are usually used as a fence or plant barrier. MC is an irregular cropping pattern for trees and agricultural products. This model is considered since no initial planning 
in plant arrangement. The variety of mixed plants lies in the targeted products, both from forestry and agricultural sectors (Wangpakapattanawong et al. 2017).

In a broader context, agroforestry with $\mathrm{TAB}$ and $\mathrm{MC}$ patterns are essential to counterweight the ecosystem from the forests condition, which continues to damage. Meanwhile, the practice of cultivating trees outside the forest continues to proliferate, such as in community forests. The development of trees outside forests increases, especially in developing countries (FAO 2020). The existence of trees in community forests also provides important values in biodiversity conservation. Biodiversity has an important role in maintaining ecosystem resilience in the face of increasing natural resource damage (environmental shocks). Also, it can improve biodiversity conservation (Schroth et al. 2004).

One of the common problems in community forests with agroforestry systems is poor knowledge, sometimes forest managers forgot the ability of plant natural regeneration. Regeneration capacity is the ability to regenerate stands to ensure their sustainability. Forest regeneration is essential in terms of stand projection and evaluation. Regenerative capacity at various levels of life stages (trees, poles, saplings, and seedlings) is an essential part of forest sustainability. Natural regeneration can be done actively or passively, while artificial regeneration is a technique of direct planting and sowing of seeds to add species and increase land productivity (Chatzichristaki and Zagas 2017).

The combination of semi-natural regeneration in agroforestry systems means that there is various level of life stages. Trees arrangement in agroforestry systems in multi-strata community forests provides an opportunity for tree harvesting to be carried out sustainably with selective cutting. Regeneration (natural and artificial) on forest land is essential because it is related to preserving standing resources in the forest (De Cauwer et al. 2018).

The capacity of regeneration can provide an overview of the abundance of plant species, so that it can be used to determine the potential and opportunities for the sustainability of agroforestry systems in community forests, especially in MC and TAB models. The purpose of this study was to determine the capacity of semi-natural regeneration in agroforestry models for small-scale farmers. The results of this study will serve as essential guidelines for the sustainability of community forest management.

\section{MATERIALS AND METHODS}

\section{Study area}

The study was conducted during June-September, 2020 in Banaran Sub-district, Playen District, Gunungkidul District, Province of Yogyakarta, Indonesia. The area has an ustic moisture regime. Annual mean temperature, relative humidity, and precipitation are $32{ }^{\circ} \mathrm{C}, 78-90 \%$, and 2000-2500 mm year-1, respectively. The study area is located $\pm 43 \mathrm{~km}$ to the south-east of downtown Yogyakarta City. Banaran Sub-district is directly adjacent to the
Wanagama Forest, an educational forest belonging to the Faculty of Forestry, Universitas Gadjah Mada. People living in the study area mostly work as forest and upland farmers with narrow land ownership $\left(<500 \mathrm{~m}^{2}\right)$.

\section{Data collection}

The study was conducted using a stratified purposive sampling method focusing on plant regeneration capacity. The samples were grouped based on the agroforestry models with an area of $\leq 500 \mathrm{~m}^{2}$. The agroforestry models consisted of mixed cropping (MC) and trees along border (TAB). The vegetation data were collected using the nested quadratic method. The sizes of sampling plots were $20 \times 20$ $\mathrm{m}$ (trees), $10 \times 10 \mathrm{~m}$ (poles), $5 \times 5 \mathrm{~m}$ (saplings), and $2 \times 2$ $\mathrm{m}$ (seedlings). The steps in selecting $\mathrm{MC}$ and $\mathrm{TAB}$ plots were identifying several plots, assigning the numbers, and choosing five plots from each community randomly. The selected plots were based on topographic similarity, including soil and geomorphological conditions (Alam 2014; Moreno-Calles et al. 2010; Rendón-Sandoval et al. 2020).

Data collection was carried out to record the number of all plant species in the sampling plots at each different life stage (trees, Ø: >19 cm; poles, Ø: 10-19 cm; sapling, Ø: $<10 \mathrm{~cm}$, height $>150 \mathrm{~cm}$; seedling, height $<150 \mathrm{~cm}$ ). The recorded parameters included height, diameter at breast height (approximately at $1.3 \mathrm{~m}$ ), crown width, outer crown height, and coordinates position.

\section{Data analysis}

The estimated average diversity was made based on the life stages levels of each site (alpha diversity: $\alpha$ ), the total diversity in all life stages levels of MC and TAB (gamma diversity: $\gamma$ ), and the relationship between $\alpha$ and $\gamma$, which reflects the changes in species composition (beta diversity: $\beta=\gamma / \alpha)$ (Whittaker 1960).

The beta diversity used the Sørensen's pairwise dissimilarity index $\left(\beta_{s \phi r}=b+c / 2 a+b+c\right)$, where $a$ represented the total number of species present in both sites (MC and $\mathrm{TAB}$ ), $b$ represented the total number of species present in neighbouring site but not in the focal site, and $\mathrm{c}$ represented the total number of species that were presented in the focused sites but not at the neighbouring site (Kole et al. 2003). The Sørensen's pairwise dissimilarity index was used to describe the spatial differentiation and differences in species richness between communities, and to obtain the total beta diversity expressed as a percentage. Furthermore, the explored the partitioning of the spatial turnover and nestedness of species assemblages (Baselga 2010). The spatial turnover, which is calculated as follow: $\left(\beta_{\text {sim }}=\min \right.$ $(b, c) / a+\min (b, c))$, predicted the replacement of some species by other species, whereas the nestedness $\left(\beta_{\text {nes }}=\beta_{\text {s } \phi r}\right.$ - $\beta_{\text {sim }}$ ) identified which sites of biotas with the smaller number of species were part of biotas at richer sites (Baselga 2010).

The estimated number of effective species was a measure of "true" diversity in the order, $q=0,1$, and 2, for perennial species (Jost 2006). The $q$ exponent determines the index's sensitivity to relative species abundance or dominant in the estimated diversity (Jost 2006; Jost and 
González-Oreja 2012; Moreno et al. 2011). When $q=0$ $\left({ }^{0} \mathrm{D}\right.$, diversity of order 0$)$, species abundance does not affect the value of $q$. When $q=1\left({ }^{1} D\right.$, diversity of order 1$)$ all species had a proportional weight to their abundance in the community, and equivalent to the exponential Shannon's entropy index calculated by the natural logarithm $\left({ }^{l} D=\exp H^{\prime}\right)$. When $q=2\left({ }^{2} D\right.$, diversity order 2$)$ the abundant species had a higher effect, and other species were discounted. This diversity can be interpreted as the number of dominant species in the community, and equivalent to the inverse value of the Simpson's dominance index $\left({ }^{2} D=1 / D\right)$.

The pooled T-tests $(\mathrm{p}<0.05)$ were to assess significant difference between $\mathrm{MC}$ and $\mathrm{TAB}$ in terms of abundance of total individuals. The analysis was performed using SAS 9.4 software (SAS Institute 2013). Furthermore, the species evenness factor $\left(E F={ }^{2} D / D\right)$, Shannon's entropy index $\left(H^{\prime}\right)$, and the Simpson's dominance index $(D)$ were calculated. The relationships between plant species in the MC and TAB models were analyzed using heat map correlation. The analysis was performed using $\mathrm{R}$ statistical software (v. 3.6.3; R Development Core Team) with the core plot and entropart package (Marcon and Hérault 2015; Wei 2013). Visualization of vegetation structure diagrams (vertical and horizontal) was performed using 3D Forest 0.42 software (Trochta et al. 2017).

\section{RESULTS AND DISCUSSION}

\section{Semi-natural regeneration capacity}

Agroforestry in community forests has the characteristic of combining space for yields of annual and perennial crops according to farmers designation. Annual crops in agroforestry in community forests are provided with a particular space called processing areas. At the same time, trees are positioned on edge, which also functions as a barrier which is called trees along border (TAB) if the processing area is further managed by planting tree species so that schemes that develop mixed cropping (MC) (Suryanto et al. 2005; Suryanto et al. 2017).

During their development, the trees experience natural and artificial rejuvenation known as semi-natural. Farmers keep natural saplings in a barrier position (by pulling out saplings and replanting them into tree-lined positions). This was done so that the cultivated land could continue to be used for annual crop cultivation. Farmers also plant tree species whose seeds come from outside the land either by buying or receiving assistance from the rehabilitation program.

The vegetation analysis in the mixed cropping (MC) and trees along border (TAB) consisted of 19 plant species. Figure 1 showed the ratio of individuals between $\mathrm{MC}$ and TAB in all life stages (trees, poles, saplings, and seedlings). The tress and poles showed that no significant difference between MC and TAB $\left(t=0.11 ; p=0.3003^{\text {ns }}\right.$ and $t=0.49$; $\left.p=0.6387^{\mathrm{ns}}\right)$. The average number of trees for $\mathrm{MC}$ and TAB were 17.82 and 12.19 , respectively, while for poles by 29.38 and 24.91, respectively. The saplings and seedlings was showed significantly difference between MC and $\mathrm{TAB}(t=6.17 ; p=0.0003 * *$ and $t=3.54 ; p=$ $\left.0.0076^{* *}\right)$. The number of saplings for $\mathrm{MC}$ and $\mathrm{TAB}$ were 296.08 and 67.26, respectively, while for seedling by 375.64 and 110.05 , respectively.

The average number of individuals at all life stages provides information on the advantages and disadvantages of each agroforestry model. The advantages of the MC model were relatively shorter to the waiting time of harvesting compared to the TAB model. This is because of the higher number of individuals in the sapling and seedling compared to the TAB model. The disadvantages of the MC model were relatively high competition among individuals of saplings and seedlings, and the poor of opportunities to develop annual crops due to lack of space and high abundance of saplings and seedlings. The TAB model had an advantage in growing annual crops, while the disadvantage was the lower perennial crop production compared to the MC because of lower the number of individuals of saplings and seedlings in the future. Suryanto et al. (2013) reported that significantly increased shade tended to reduce maize physiological responses and yields. Light shade is identical to the TAB model, while moderate to heavy shade is identical to the MC model.

The ability to regulate the presence of trees at various levels that support the sustainable harvesting of perennial and annual crops is called the ability to regenerate agroforestry systems in community forests. The ability to regenerate is closely related to perennial and annual crop resources arrangement to take place sustainability. Natural regeneration in community forests will impact the dominance of trees in resource utilization, thereby reducing the space for annual crop cultivation. On this basis, it is necessary to regulate the regeneration capacity for resource optimization that combines perennial and annual crops for sustainable harvesting.

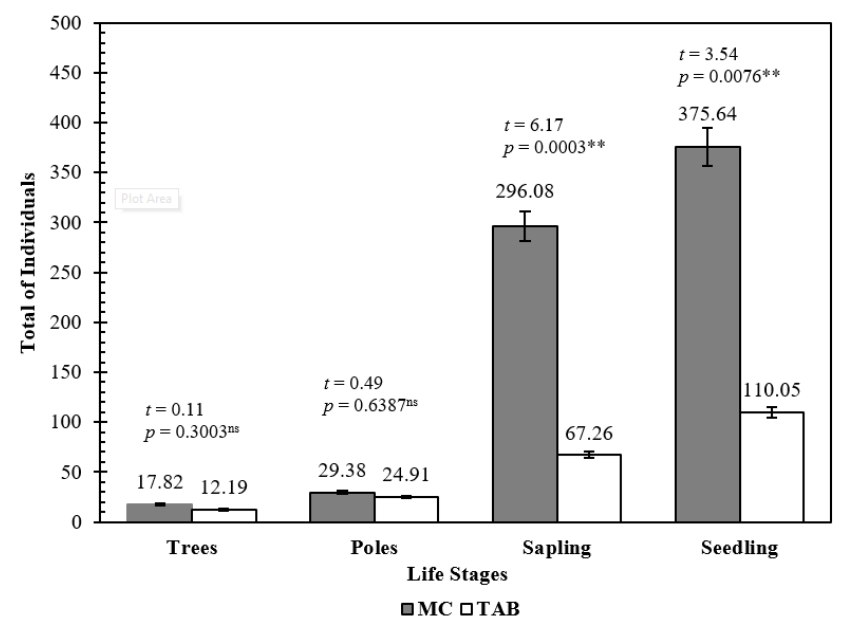

Figure 1. Average abundance of individuals of plant species (recorded in 10 sampling sites of $500 \mathrm{~m}^{2}$ ) of mixed cropping (MC) and trees along border (TAB). The ${ }^{\mathrm{ns}}$ and $* *$ were no significant and very significant difference at Pooled t-test $(p<0.05)$. Error bars indicated 95\% confidence intervals 
The study recommends annual pruning in the $\mathrm{MC}$ model for optimal stand growth, while in the TAB model, it is the enrichment planting in sapling and seedling levels. Annual pruning is required for sustainable production (Retamales and Hancock 2012). Pruning on the MC model can reduce shade to improve the macro and micro climate between stands and air temperature and wind speed to increase the yield of annual and perennial crops (Bosi 2017). Pruning is essential to optimize the relationship between shoot growth, leaf area, photosynthesis, and good productivity and quality (Demirtas et al. 2010). The effects of not pruning are shorter shoots, low canopy architecture, and poor plant growth (Müller 2011).

Figure 2 showed the vegetation structure diagram consisted of various individuals forming the space (vertical and horizontal). The vertical structure describes the distribution of the number of individuals in various canopy layers, while the horizontal structure describes the distribution of individual plant species with their dimensions. The vertical structure of the MC model was divided into two canopy layers, i.e. stratum $\mathrm{C}$ and stratum D. Stratum C with a height of 5-19 m consisted of Acacia auriculiformis, Gmelina arborea, Tectona grandis, Swietenia macrophylla, Acacia mangium, Mangifera indica, Bauhinia purpurea, and Leucaena leucocephala. Stratum D with a height of 1-4 m consisted of Tectona grandis and Bauhinia purpurea. The highest stratum of the
MC model was only up to $19 \mathrm{~m}$ because the farmers harvested many higher trees. The horizontal space in the MC model showed that the distribution of individuals has random patterns.

The vertical structure of the TAB model was divided into three canopy layers, namely stratum B, stratum C, and stratum D. Stratum B with a height of 20-30 m consisted of Swietenia macrophylla, Acacia mangium, and Tectona grandis. Stratum C with a height of 5-19 m consisted of Acacia auriculiformis, Anacardium occidentale, Tectona grandis, Swietenia macrophylla, Acacia mangium, and Hibiscus tiliaceus, while stratum D with a height of 1-4 m consisted of Tectona grandis. The stratum layer was influenced by competition and the level of tolerance among individuals of plant species to the sunlight. Also, the stratum layer showed the class of age of each vegetation that formed the forest (Figure 2). In the TAB model, the vegetation can reach $30 \mathrm{~m}$ because the farmers rarely harvested the trees, and focused more on cultivating annual crops. The growth of perennial crops can reach a maximum height due to the influence of fertilization used by the farmers, so that it will have a positive impact on the yield of perennial crops. The number of individuals and the stand structure can describe the rate of individuals availability at each life stage. This affects natural and semi-natural regenerations or stands growth, including the speed of selfrecovery after cutting treatment (Muhdin et al. 2012).

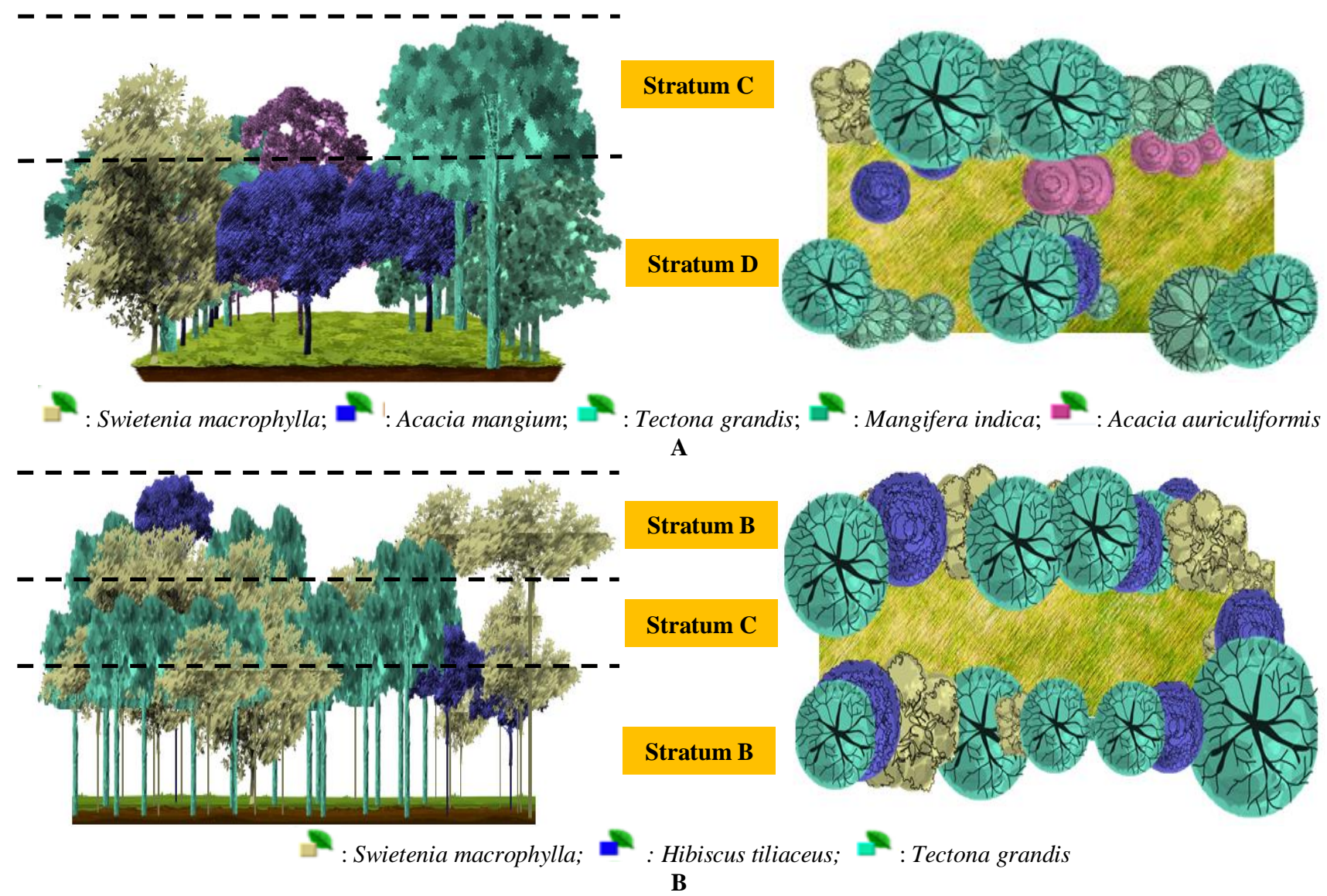

Figure 2. Vegetation structure diagrams (vertical and horizontal) of individuals of plants. A). Mixed cropping (MC) and B). Trees along border $(\mathrm{TAB})$ 
Total species richness $\left({ }^{0} D\right)$ in the $\mathrm{MC}$ and the TAB were similar (36 and 31 species, respectively), as well as the effective number or communities estimated for alpha, beta, and gamma diversity of order $1\left({ }^{1} D\right)$ and $2\left({ }^{2} D\right)$ (Figure 3). However, the average alpha diversity was higher in the MC $\left({ }^{0} D_{\alpha}=9.00,{ }^{1} D_{\alpha}=4.19\right.$, and ${ }^{2} D_{\alpha}=3.33$ effective species), compared to the TAB $\left({ }^{0} D_{\alpha}=7.75,{ }^{1} D_{\alpha}=3.74\right.$, and ${ }^{2} D_{\alpha}=2.56$ effective species) (Figure 3.A and Table 1).

The beta diversity among sites as indicated by the same values of the sufficient number of communities in the MC for the order of $0\left({ }^{0} \mathrm{D}=4.00\right.$ versus 4.00 in TAB $)$, indicated that the species turnover in the MC and the TAB models were relatively same. The species in $\mathrm{MC}$ and $\mathrm{TAB}$ were not replaced $\left({ }^{l} D_{\beta}=3.85\right.$ and 3.81 effective communities, respectively), whereas the displacement of the dominant species in the TAB was higher $\left({ }^{2} D_{\beta}=4.40\right)$, compared to the $\mathrm{MC}\left({ }^{2} D_{\beta}=4.36\right)$ (Figure 3.B).

The MC had $62 \%$ dissimilarity among sites $\left(\beta_{\text {sor }}=0.62\right.$ $\pm 0.24), 54 \%$ of which was due to species turnover $\left(\beta_{\text {sim }}=\right.$ $0.54)$ and $5 \%$ due to the nestedness $\left(\beta_{\text {nes }}=0.052\right)$, which was according to the number of singletons and doubletons showed in the TAB. The TAB sites had 54\% dissimilarity $\left(\beta_{\text {sor }}=0.54 \pm 0.32\right), 64 \%$ of it due to the species turnover $\left(\beta_{\text {sim }}=0.64\right)$ and $4 \%$ due to the nestedness $(\beta n e s=0.041)$, with fewer singletons and doubletons (Moreno-Calles et al. 2020).

The gamma diversity showed a significant difference between MC and TAB. The gamma diversities of orders 1 $\left({ }^{l} D_{\gamma}\right)$ and $2\left({ }^{2} D_{\gamma}\right)$ in the MC were higher $\left({ }^{1} D_{\gamma}=16.14\right.$ and ${ }^{2} D_{\gamma}=14.52$ effective species, respectively), compared to the TAB ( ${ }^{1} D_{\gamma}=14.25$ and ${ }^{2} D_{\gamma}=11.26$ effective species), and the opposite pattern was found for total species richness (Figure 3.C and Table 1). The $\mathrm{MC}$ is more equitable community (evenness factor $=0.423$ ), compared to TAB (evenness factor $=0.314)$ (Table 1). The estimated values of the Shannon's $\left(H^{\prime}\right)$ and Simpson's $(D)$ indices of the MC showed lower entropy $\left(H^{\prime}=3.94\right.$ nats $)$ and higher dominance $(D=0.024)$ compared to the TAB $\left(H^{\prime}=4.05\right.$ nats; $\left.D=0.032\right)$.

Certain species indicate good regeneration ability at the tree, poles, sapling, and seedling levels. Its good distribution capacity can influence a species' dominance in seed shape, pollen size, and dispersing agents such as wind, water, birds, mammals, and humans (Nur et al. 2016). Wakjira (2006) informed that the high dominance and abundance of some forest species could be attributed to several factors, such as overharvesting of desired species, disturbance factors, forest succession stages, or species survival strategies.

\section{Floristic composition}

The floristic composition is an essential element to visualize anthropogenic activities and environmental factors that affect an areas vegetation. This is useful for forest management (Kuma and Shibru 2015). Mixed cropping (MC) showed a significantly higher abundance of individuals $(719 ; 180 \pm 183.25$ per site; $\min .18$, $\max .376)$, and species diversity $(9 \pm 1.41$; min. 8 , max. 11), compared to trees along border (TAB) with 214 individuals (54 \pm 44.27 per site; $\min 12$, max. 110$)$, and species diversity (8 \pm 2.75 ; $\min .5$, $\max .11$ ) (Table 1).
The most abundant plant species in MC were Swietenia macrophylla (6411 individuals ha ${ }^{-1}$ or $44.59 \%$ ), Bauhinia purpurea (3198 individuals $\mathrm{ha}^{-1}$ or $22.24 \%$ ), and Tectona grandis (2421 individuals ha ${ }^{-1}$ or $16.84 \%$ ), while the lowest species was Moringa oleifera ( 8 individuals ha-1 or $0.06 \%$ ). The most common and abundant plant species in TAB were Swietenia macrophylla (1712 individuals $\mathrm{ha}^{-1}$ or $39.93 \%$ ), Bauhinia purpurea (999 individuals $\mathrm{ha}^{-1}$ or $23.30 \%$ ), and Tectona grandis (936 individuals ha ${ }^{-1}$ or $21.82 \%$ ), while the lowest was Terminalia catappa (6 individuals $\mathrm{ha}^{-1}$ or $0.13 \%$ ) (Figure 4 and 5).

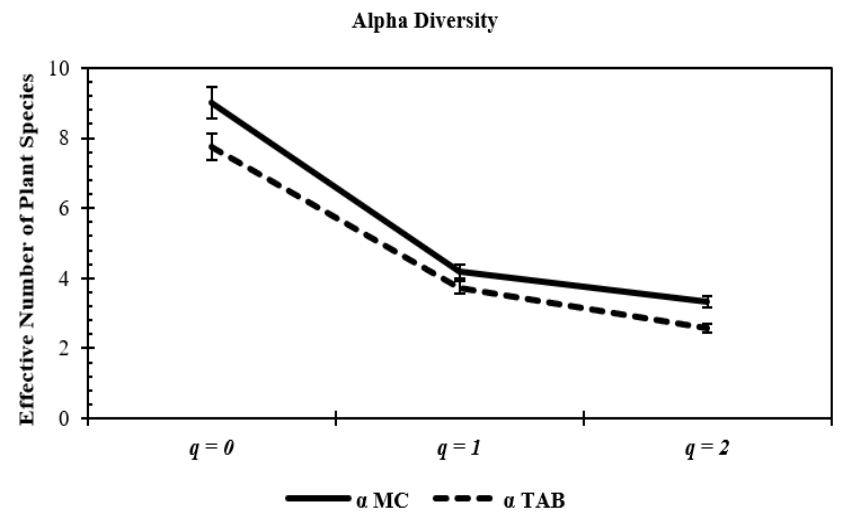

A

Beta Diversity
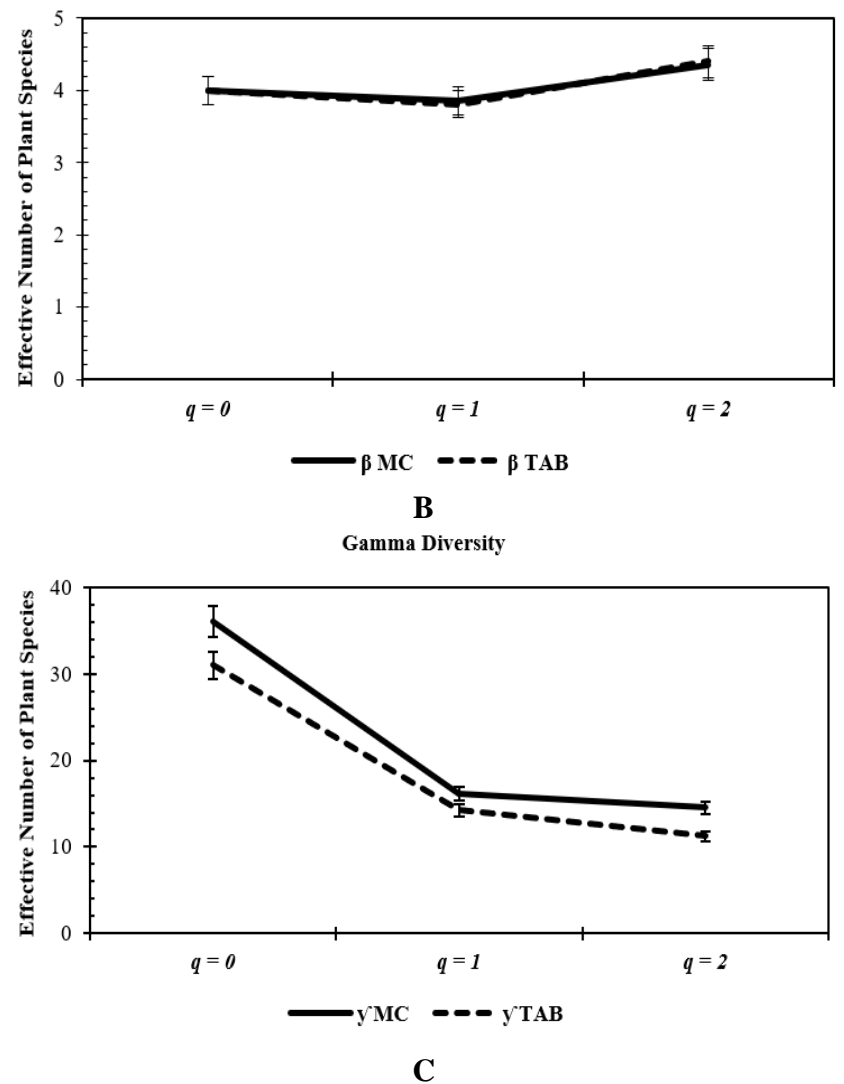

Figure 3. Diversity profiles of plant species (recorded in 10 sampling sites of $500 \mathrm{~m}^{2}$ ) of mixed cropping (MC: continuous line) and trees along border (TAB: dotted line). A). Average alpha diversity $(\alpha)$ among sites, B). Beta diversity $(\beta)$ among communities, and C). Gamma diversity $(\gamma)$. Error bars indicated 95\% confidence intervals 
Swietenia macrophylla, Bauhinia purpurea, and Tectona grandis were listed as top-three plant species according to individual abundance in $\mathrm{MC}$ and $\mathrm{TAB}$. This is because the study areas are very suitable for the growth of the three habitus, besides that the three plant species have relatively high economic value compared to other plant species.

\section{Reasons for keeping the agroforestry system models}

Material uses included foods (roots, stems, leaves, flowers, or fruits), medicines, crafts, building materials, fodders, firewoods. Non-material uses included ornamentals, ceremonies, and rituals. Ecological uses included shade, erosion and landslides prevention, soil fertility, and water cycle control (Figure 6).

Tabel 1. Diversity values (from 10 sampling sites of $500 \mathrm{~m}^{2}$ ) of the plant species of mixed cropping (MC) and trees along border (TAB)

\begin{tabular}{|c|c|c|c|c|c|c|c|c|}
\hline $\begin{array}{l}\text { Agroforestry } \\
\text { models }\end{array}$ & Life stages & $\begin{array}{l}\text { Abundance of } \\
\text { individuals }\end{array}$ & \begin{tabular}{l}
\multicolumn{1}{c}{${ }^{0} D$} \\
(Species \\
richness)
\end{tabular} & $\begin{array}{c}{ }^{I} D \\
\text { (Typical } \\
\text { species) }\end{array}$ & $\begin{array}{l}{ }^{2} D \\
\text { (Dominant } \\
\text { species) }\end{array}$ & $\begin{array}{l}\text { Evenness } \\
\text { factor } \\
\left({ }^{2} D /^{\circ} D\right)\end{array}$ & $\begin{array}{c}\text { Shannon } \\
\left(H^{\prime}\right)\end{array}$ & $\begin{array}{c}\text { Simpson } \\
(D)\end{array}$ \\
\hline \multirow{4}{*}{$\begin{array}{l}\text { Mixed Cropping } \\
\text { (MC) }\end{array}$} & Trees & 18 & 9 & 4.22 & 3.85 & 0.43 & 1.44 & 0.26 \\
\hline & Poles & 29 & 8 & 4.52 & 4.00 & 0.50 & 1.51 & 0.25 \\
\hline & Sapling & 296 & 11 & 5.50 & 4.55 & 0.41 & 1.70 & 0.22 \\
\hline & Seedling & 376 & 8 & 2.95 & 2.13 & 0.27 & 1.08 & 0.47 \\
\hline Alpha Diversity $(\alpha)$ & & $179.73 \pm 183.25$ & $9.00 \pm 1.41$ & $4.19 \pm 1.05$ & $3.33 \pm 1.05$ & 0.37 & 1.43 & 0.30 \\
\hline Gamma Diversity $(Y)$ & & 718.91 & 36.00 & 16.14 & 14.52 & 0.40 & 1.97 & 0.08 \\
\hline Trees Along Border & Trees & 12 & 5 & 3.33 & 2.58 & 0.52 & 1.20 & 0.39 \\
\hline \multirow{3}{*}{ (TAB) } & Poles & 25 & 6 & 2.89 & 2.32 & 0.39 & 1.06 & 0.43 \\
\hline & Sapling & 67 & 11 & 5.54 & 4.33 & 0.39 & 1.71 & 0.23 \\
\hline & Seedling & 110 & 9 & 3.67 & 2.02 & 0.22 & 1.30 & 0.49 \\
\hline Alpha Diversity $(\alpha)$ & & $53.53 \pm 44.27$ & $7.75 \pm 2.75$ & $3.74 \pm 1.17$ & $2.56 \pm 1.03$ & 0.33 & 1.32 & 0.39 \\
\hline Gamma Diversity $(\Upsilon)$ & & 214.12 & 31.00 & 14.25 & 11.26 & 0.36 & 1.81 & 0.10 \\
\hline
\end{tabular}

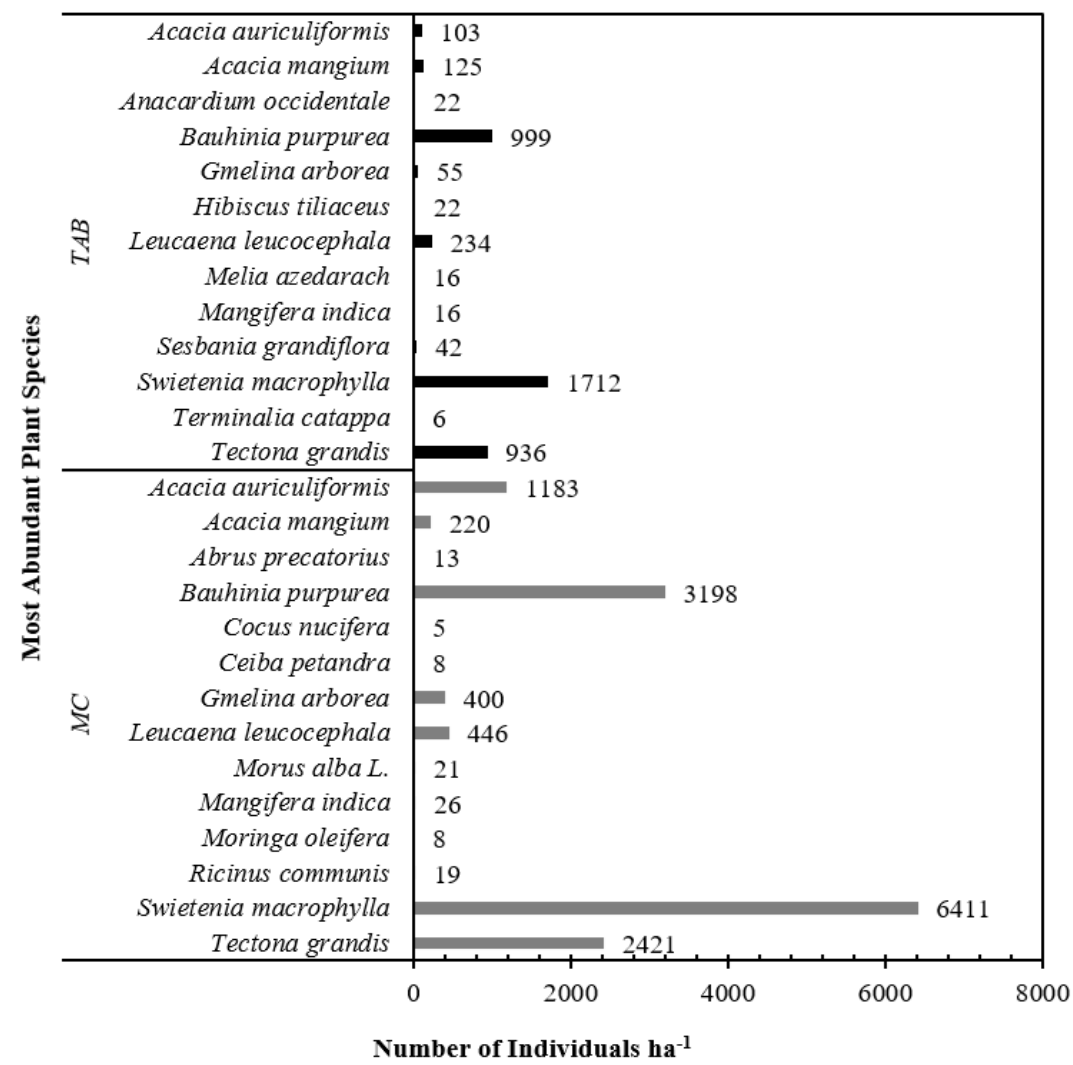

Figure 4. Relative density (extrapolated to $1 \mathrm{ha}$ ) of the most abundant plant species (recorded in 10 sampling sites of $500 \mathrm{~m}^{2}$ ) of mixed cropping (MC: grey bars) and trees along border (TAB: black bars) 


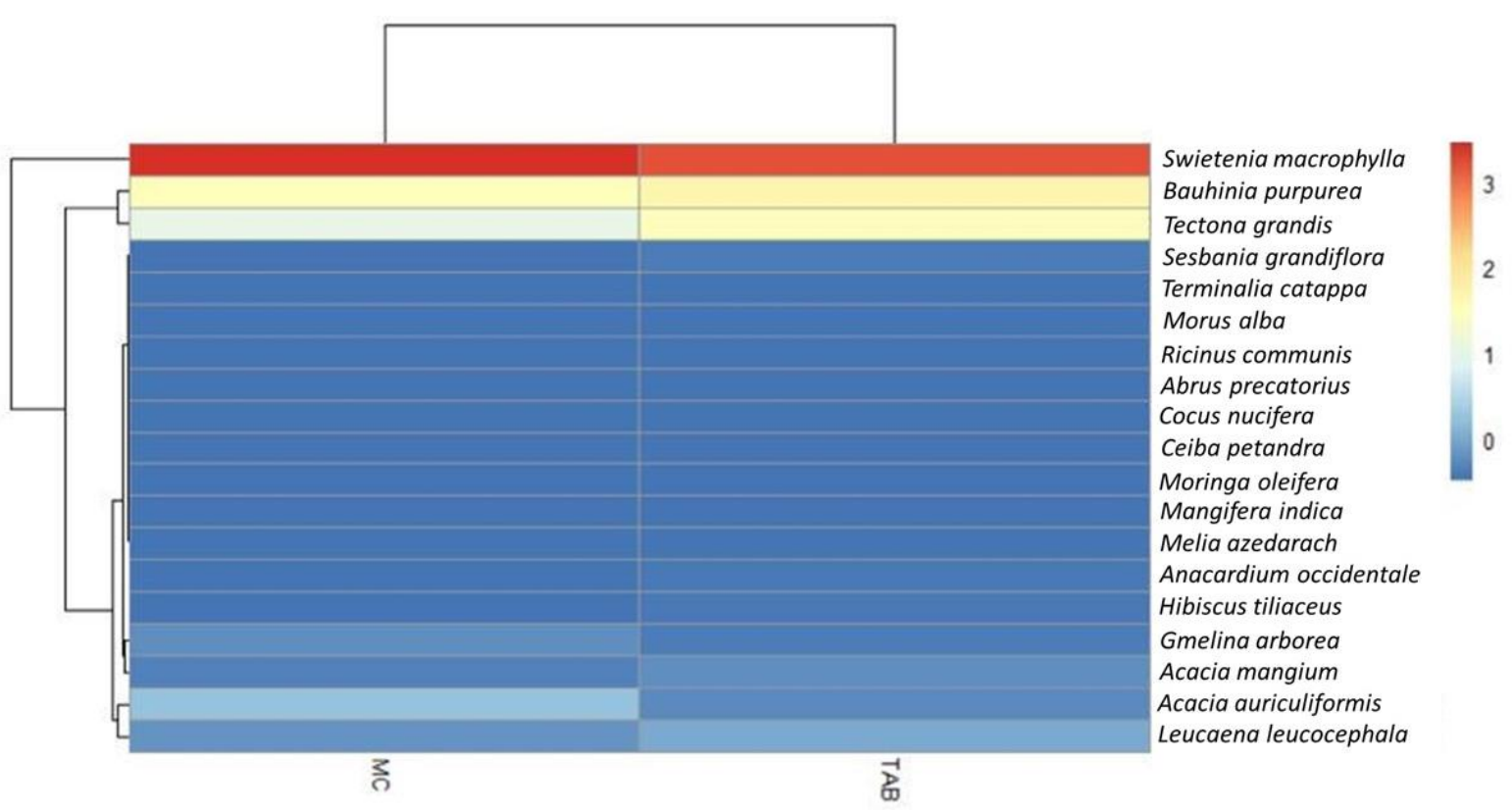

Figure 5. The relationships among plant species in the $\mathrm{MC}$ and the $\mathrm{TAB}$ models, analyzed using heat map correlation

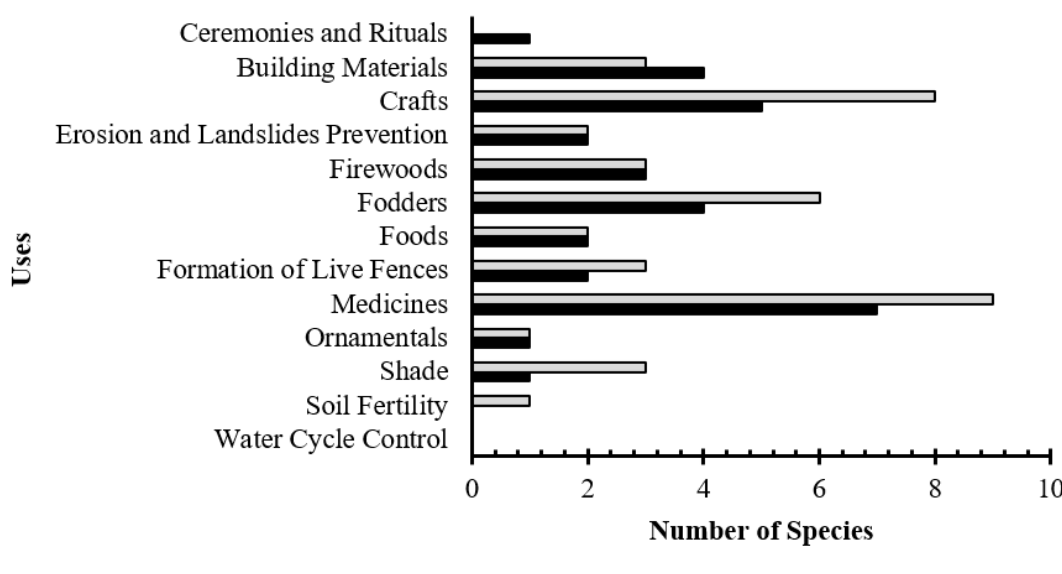

口TAB ШMC

Figure 6. Main uses of plant species to the satisfaction of human needs. Mixed cropping (MC: black bars) and trees along border (TAB: grey bars)

Figure 6 provided information related to the uses of plant species. Many species have more than one usecategory. In the MC, the top-three significant uses were medicines (7 species), crafts (5 species), and building materials (4 species), while in the TAB showed that the top-three significant uses were medicines ( 9 species), crafts ( 8 species), and fodders (6 species). Things that need to be considered in the MC and TAB models are the low number of plant species for ecological services, i.e. erosion and landslides prevention, water cycle control, and soil fertility (Figure 6).

Agroforestry practices contribute to a wide range of products and services. Trees may provide food, shelter, energy, medicine, cash income, raw materials for crafts, fodder and forage, and resources to meet social obligations. Trees used in agroforestry systems can also provide a variety of services, such as being a form of saving and investment and contributing to the improvement of soil fertility for crop production (World Agroforestry Centre 2011).

\section{ACKNOWLEDGEMENTS}

The study was funded by Universitas Gadjah Mada through the university grant-in-aid scheme under PDUPT 2020 (No: 2767/UN1.DITLIT/DIT-LIT/PT/2020). 


\section{REFERENCES}

Alam T. 2014. Optimization Management of Clove, Cacao, Cardamom Agroforestry System in Menoreh Mountain Area. [Thesis]. Universitas Gadjah Mada, Yogyakarta. [Indonesian]

Baselga A. 2010. Partitioning the turnover and nestedness components of beta diversity. Glob Ecol Biogeogr 19: 134-143.

Bosi C. 2017. Parameterization and evaluation of mechanistic crop model for estimating Urochloa brizantha cv. bps plata productivity under full sun and in silvopastoral system. [Dissertation]. Luiz de Queiroz College of Agriculture, University of Sao Paulo, Brazil.

Bowler DE, Buyung-Ali LM, Healey JR, Jones JPG, Knight TM, Andrew S Pullin, AS. 2011. Does community forest management provide global environmental benefits and improve local welfare?. Front Ecol Environ 10 (1): 29-36.

Chatzichristaki C, Zagas, T. 2017. The contribution of natural and artificial regeneration at the restoration of fire-affected Peri-Urban forest of Thessaloniki (Northern Greece). GlobalNEST Intl J 19 (191): 29-36.

De Cauwer V, Knox N, Kobue-Lekalake R, Lepetu JP, Matenanga O, Naidoo S, Nott A, Parduhn D, Sichone P, Tshwenyane S, Yeboah E, Revermann R. 2018. Woodland resources and management in southern Africa. In: Revermann R, Krewenka KM, Schmiedel U, Olwoch JM, Helmschrot J, Jürgens N (eds.). Biodiversity and Ecology. Klaus Hess Publishers, Göttingen and Windhoe, Germany.

De Royer S, Van Noordwijk M, Roshetko JM. 2018. Does communitybased forest management in Indonesia devolve social justice or social costs?. Int For Rev 20 (2): 167-180.

Demirtas MN, Bolat, Ercisli L, Holmez OOIA, Altindag SM, Celik B. 2010. The effects of different pruning treatments on seasona variation of carbohydrates in 'hacihaliloglu' apricot cultivar. Not Bot Horti Agrobot Cluj-Napoca 38: 223-227.

FAO. $2015 . \quad$ Agroforestry. http://www.fao.org/forestry/agroforestry/80338/en/

FAO. 2020. The State of the World's Forests. http://www.fao.org/state-offorests/en/.

Jost L, González-Oreja JA. 2012. Midiendo la diversidad biológica; más allá del índice de Shannon. Acta Zoológica Lilloana 56: 3-14.

Jost L. 2006. Entropy and diversity. Oikos 113: 363-375.

Kole P, Gaston KJ, Lennon JJ. 2003. Measuring beta diversity for presence-absence data. J Anim Ecol 72: 367-382.

Kuma M, Shibru S. 2015. Floristic composition, vegetation structure, and regeneration status of woody plant species of oda forest of humbo carbon project, Wolaita, Ethiopia. J Bot 2015: 1-9.

Marcon E, Hérault B. 2015. Entropart; an R package to measure and partition diversity. J Stat Softw 67: 1-26.

Moreno CE, Barragán F, Pineda E, Pavón NP. 2011. Reanálisis de la diversidad alfa; alternativas para interpretar y comparar información sobre comunidades ecológicas. Rev Mex Biodivers 82: 1249-1261.

Moreno-Calles AI, Casas A, Blancas J, Torres I, Masera O, Caballero J, García-Barrios LE, Pérez-Negrón E, Rangel-Landa S. 2010 Agroforestry systems and biodiversity conservation in arid zones; the case of the Tehuacán Valley, Central México. Agrofor Syst 80: 315 331

Muhdin E, Suhendang, D, Wahjono H, Purnomo, Istomo, Simangunsong BCH. 2008. Keragaman struktur tegakan hutan alam sekunder. Jurnal Manajemen Hutan Tropika 16(2): 81-87. [Indonesian]

Müller JL. 2011. Pruning and pollination studies on southern highbush blueberries. [Thesis]. University of Stellenbosch, Stellenbosch, South Africa.

Muschler R. 2016. Agroforestry; essential for sustainable and climate smart land use?. In: Pancel L, Köhl M, (2 ${ }^{\text {nd }}$ eds) Tropical Forestry Handbook. Springer-Verlag: Berlin, Heidelberg, Germany.
Nur A, Nandi R, Jashimuddin M, Hossain MA. 2016. Tree species composition and regeneration status of Shitalpur forest beat under Chittagong north forest division, Bangladesh. Adv Ecol 2016: 1-7. DOI: $10.1155 / 2016 / 5947874$

Rendón-Sandoval FJ, Casas A, Moreno-Calles AI, Torres-García I, García-Frapolli E. 2020. Traditional agroforestry systems and conservation of native plant diversity of seasonally dry tropical forests. Sustain 12: 4600; doi:10.3390/su12114600.

Retamales JB, Hancock JF. 2012. Blueberries. CABI Publishing, Wallingford, UK.

Sabarnurudin MS, Budiadi, Suryanto P. 2011. Agroforestri untuk Indonesia; Strategi Kelestarian Hutan dan Kemakmuran. Cakrawala Media, Yogyakarta. [Indonesian]

SAS Institute. 2013. SAS System for Windows 9.4. SAS Institute, Inc., North Carolina, USA.

Schroth G, da Fonseca GAB, Harvey CA, Vasconcelos HL, Gascon C, Izac AMN. 2004. Introduction; the role of agroforestry in biodiversity conservation in tropical landscapes. In: Schroth G, da Fonseca GAB, Harvey CA, Gascon C (eds.). Agroforestry and Biodiversity Conservation in Tropical Landscapes. Island Press, Washington, USA.

Suryanto P, Budiadi, Sabarnurdin MS. 2017. Silvikultur agroforestri dan masa depan hutan rakyat. In: Maryudi A, Nawir AA (eds.). Hutan Rakyat di Simpang Jalan. Gadjah Mada University Press, Yogyakarta. [Indonesia]

Suryanto P, Putra ETS, Kurniawan S, Suwignyo B, Prianto SDA. 2013. Maize response at three levels of shade and its improvement with intensive agroforestry regimes in Gunung Kidul, Java, Indonesia. Proc Environ Sci 20: 370-376.

Suryanto P, Tohari, Sabarnurudin MS. 2005. Dinamika sistem berbagi sumberdaya (resources sharing) dalam agroforestri; dasar pertimbangan penyusunan strategi silvikultur. Ilmu Pertanian 12 (2): 165-178. [Indonesian].

Trochta J, Krůček M, Vrška T, Král K. 2017. 3D Forest; an application for descriptions of three-dimensional forest structures using terrestrial LiDAR. PLoS ONE 12 (5): e0176871. DOI: 10.1371/journal.pone.0176871.

Wakjira FS. 2006. Biodiversity and ecology of afromontane rainforests with wild Coffea arabica L. populations in Ethiopia. [Dissertation]. University of Bonn, Germany.

Wangpakapattanawong P, Finlayson P, Öborn I, Roshetko JM, Sinclair F, Shono K, Borelli S, Hillbrand A, Conigliaro M. 2017. Agroforestry in Rice-Production Landscapes in Southeast Asia; A Practical Manual. Food and Agriculture Organization of the United Nations Regional Office for Asia and the Pacific, Bangkok, Thailand \& World Agroforestry Centre (ICRAF) Southeast Asia Regional Program, Bogor, Indonesia

Wei T. 2013. Corrplot: Visualization of a correlation matrix. R Package Version 073

Whittaker RH. 1960. Vegetation of the Siskiyou Mountains, Oregon and California. Ecol Monogr 30: 279-338.

World Agroforestry Centre. 2011. Annual Report 2010-2011 of World Agroforestry Centre; Wicked Challenges Today, Wicked Solutions Tomorrow. World Agroforestry Centre, Nairobi, Kenya.

Xu H, Bi H, Gao L, Yun L. 2019. Alley cropping increases land use efficiency and economic profitability across the combination cultivation period. Agronomy 9 (1): 34 . DOI: 10.3390/agronomy9010034.

Yogyakarta Provincial Environment and Forestry Service. 2019. $\begin{array}{llll}\text { Handbook of } & \text { Forestry } & \text { Statistic } & 2019 .\end{array}$ http://dlhk.jogjaprov.go.id/storage/files/Buku\%20Data\%20Statistik\% 20Kehutanan\%20DIY\%202019.pdf. 